\title{
ANALISIS KESULITAN BELAJAR OPERASI PERKALIAN PADA SISWA SEKOLAH MENENGAH PERTAMA (SMP)
}

\author{
Clara Fatimah ${ }^{1}$, Ketut Wirnawa ${ }^{2}$, Putri Sukma Dewi ${ }^{3}$ \\ Universitas Teknokrat Indonesia ${ }^{\mathbf{1 , 2 , 3}}$ \\ clarafatimah20@gmail.com
}

\begin{abstract}
Received: Mei 2020
Accepted: Juni 2020

Abstract

Mathematical learning can never be separated from the arithmetic operations of addition, subtraction, multiplication and division operations. Arithmetic operations that are still widely complained of by junior high school students or equivalent are multiplication arithmetic operations. This study aims to determine the location of students' difficulties in multiplication operations. The analysis technique in this article uses quantitative methods with descriptive and inferential statistical techniques. The subjects of this study were 25 junior high students in Lampung Province. Difficulties faced by students is that it is difficult to understand the intentions of the questions which reach $40 \%$, these difficulties which trigger other difficulties arise. These difficulties include unit multiplication operations, tens, hundreds to thousands. Researchers collected data using a Google form web-based interactive service questionnaire by giving a test in the form of 10 story questions and a column of reasons for difficulty while working on the questions. The questions given refer to the level of difficulty, the validity of the questions with the Product Moment correlation technique for each item and the reliability that reaches 0.707 using the Cronbach Alpha method. Obtained 55\% of junior high school students or equivalent difficulty when working on the problem.
\end{abstract}

Published: Juni 2020

Keywords: Multiplication, Junior high school, Student difficulties.

\begin{abstract}
Abstrak
Pembelajaran matematika tidak pernah terlepas dari operasi hitung baik operasi penjumlahan, pengurangan, perkalian maupun pembagian. Operasi hitung yang masih banyak dikeluhkan oleh siswa Sekolah Menengah Pertama (SMP) atau sederajat adalah operasi hitung perkalian. Penelitian ini bertujuan untuk mengetahui letak kesulitan siswa dalam operasi perkalian. Teknik analisis pada artikel ini menggunakan metode kuantitatif dengan teknik statistik deskriptif dan inferensial. Subjek penelitian ini adalah 25 siswa SMP di Provinsi Lampung. Kesulitan yang dihadapi siswa yaitu sulit untuk memahami maksud soal yang mencapai $40 \%$, kesulitan ini yang memicu kesulitan-kesulitan lainnya muncul. Kesulitan tersebut meliputi operasi perkalian satuan, puluhan, ratusan hingga ribuan. Peneliti mengumpulkan data menggunakan kuesioner layanan interaktif berbasis web google form dengan memberikan tes berupa 10 soal cerita dan kolom alasan kesulitan saat pengerjaan soal. Soal yang diberikan mengacu pada tingkat kesukaran, kevalidan soal dengan teknik korelasi Product Moment tiap butir soal serta reabilitas yang mencapai 0,707 menggunakan metode Cronbach Alpha. Didapat 55\% siswa SMP atau sederajat kesulitan saat mengerjakan soal tersebut.
\end{abstract}

Kata Kunci: Perkalian, SMP, Kesulitan siswa 


\section{PENDAHULUAN}

Matematika merupakan ilmu dasar tentang logika mengenai bentuk, susunan, besaran dan konsep-konsep berhubungan lainnya dengan jumlah yang banyak dan terbagi ke dalam 3 bidang yaitu: aljabar, analisis, dan geometri (Sariningsih \& Purwasih, 2017). Operasi hitung yang biasa kita temui dalam matematika yaitu penjumlahan, pengurangan, perkalian dan pembagian. Pembelajaran matematika tidak pernah terlepas dengan operasi hitung baik operasi penjumlahan, pengurangan, perkalian maupun pembagian (Untari, 2013). Dalam mengoperasikan bilangan dalam bentuk penjumlahan dan pengurangan cukup mudah untuk diterapkan dikehidupan sehari-hari atau dengan cara mengintegrasikan budaya pada setiap mata pelajaran matematika (Maskar \& Anderha, 2019). Sedangkan untuk operasi perkalian dan pembagian sebagian orang masih banyak mengeluhkan kesulitannya. Apalagi dimasa ini, banyak siswa Sekolah Menengah Pertama (SMP) yang tidak dapat memahami bagaimana cara mengalikan bilangan dengan baik. Inilah yang menumbuhkan presepsi bahwa mempelajari ilmu matematika itu sulit dan menakutkan.

Matematika adalah salah satu topik yang cukup ditakuti dan tidak disukai oleh siswa (Wulandari \& Sagita, 2011). Rasa takut yang berlebihan ini yang membuat siswa tidak dapat mengikuti proses pembelajaran matematika dengan baik. Sehingga, siswa kerap kali merasa kesulitan dalam mengikuti pelajaran matematika. Putri \& Dewi (2020) menyatakan bahwa proses pembelajaran matematika pada dasarnya bukan sekedar transfer gagasan namun proses mengkontruksi pengetahuan siswa. Tuntutan hidup yang semakin besar dan kompetitif pada masa modern rentan menimbulkan kecemasan, stres, dan depresi (Muhajarah, 2018). Tuntutan ini dapat berasal dari internal maupun ekternal membuat siswa mudah merasa kesulitan untuk melakukan sesuatu hal. Termasuk kesulitan dalam pembelajaran matematika. Peraturan Menteri Pendidikan Nasional Republik Indonesia Nomor 22 Tahun 2006 tentang Standar Isi pada butir kelima yang memperkuat aspek psikologis dalam pembelajaran matematika menyebutkan bahwa pembelajaran matematika bertujuan agar peserta didik memiliki sikap menghargai kegunaan matematika dalam kehidupan, yaitu: memiliki rasa ingin tahu, perhatian, dan minat dalam mempelajari matematika, serta sikap ulet, dan percaya diri dalam pemecahan masalah. Belum maksimalnya kemampuan pemecahan masalah matematika tidak hanya disebabkan oleh sifat matematika yang abstrak tersebut tetapi juga tidak terlepas dari proses pembelajaran matematika yang ada dalam setiap kelasnya selama ini yaitu guru hanya menerangkan materi, memberi contoh soal dan memberikan latihan soal (Amri \& Abadi, 2013).

Tentu saja setiap pelaksanaan pembelajaran tidak selalu berjalan baik, banyak kesulitan yang dihadapi. Menurut Supardi (2013) keberhasilan siswa dalam pembelajaran tergantung pada bagaimana cara siswa mengatasi kesulitan yang ada. Kesulitan atau kendala belajar yang dialami siswa dapat disebabkan oleh faktor internal dan eksternal. Suryabrata (2014) mengungkapkan yang termasuk faktor internal adalah fisiologis dan psikologis misalnya: kecerdasan, motivasi, prestasi, dan kemampuan kognitif. Faktor eks-ternal adalah faktor lingkungan dan instrumental misal: sekolah, guru, kurikulum, dan model pembelajaran. Kesulitan siswa dalam belajar matematika adalah kesulitan konsep, ada 3 hal yang menyebabkan siswa mengalami kesulitan dalam belajar matematika diantaranya adalah persepsi (perhitungan matematika), intervensi dan ekstrafolasi pelaksanaan proses belajar mengajar akan sangat menentukan sejauh mana keberhasilan yang harus dicapai oleh suatu mata pelajaran matematika. Puspaningtyas (2019) menyatakan kemampuan yang bisa dikembangkan melalui pembelejaran matematika adalah kemampuan berpikir.

Fakta bahwa ada siswa saat ini yang mudah menyerah dalam mengerjakan soal matematika adalah karena kesulitan dalam proses penyelesaian masalah yang mereka hadapi (Hidayat, 2017; Hidayat et al., 2018). Aspek kesulitan siswa dalam operasi hitung perkalian setiap orang pasti berbeda-beda. Mulai dari kesulitan mengalikan bilangan ganjil, kesulitan mengalikan bilangan berulang, kesulitan mengalikan bilangan puluhan hingga ribuan. Menurut Ulfa (2019) untuk mengantisipasi masalah yang timbul pada matematika harus diterapkan stategi pembelajaran yang sesuai agar siswa dapat maksimal dalam belajar dan mengembangkan kreativitasnya dalam berfikir, dengan begitu pemahaman konsep matematika pada siswa meningkat. Penelitian ini bertujuan untuk mengetahui sejauh mana siswa Sekolah Menengah Pertama (SMP) atau sederajat dalam menalar soal cerita bentuk operasi hitung perkalian dan mengoperasikannya. Sehingga, peneliti mengetahui letak kesulitan siswa dalam operasi perkalian.

\section{METODE}

Sesuai dengan tujuan penelitian yaitu menganalisis kesulitan operasi perkalian pada siswa Sekolah Menengah Pertama (SMP), penelitian ini menggunakan metode kuantiatif dengan teknik statistika deskriptif dan inferensial dengan mencari hubungan satu variabel dengan variabel yang lain (Sugiyono, 2016). Subjek penelitian ini adalah siswa SMP atau sederajat yang berada di Provinsi Lampung yang berjumlah 25 siswa.

Metode pengumpulan data dilakukan dengan memberikan kuisioner kepada responden menggunakan layanan interaktif berbasis web yaitu google form di https://forms.gle/MxGCfzdxZLHeA6qs9. Kuesioner adalah suatu instrumen pengumpulan data yang digunakan untuk mengumpulkan data dalam jumlah yang besar (Ismail \& AlBahri, 2019). Caranya dengan memberikan sejumlah pertanyaan tertulis secara terstruktur kepada respoden 
berkaitan degan tanggapannya terhadap berbagai variabel yang diteliti (Muchlis, Christian, \& Sari, 2019). Kuesioner survey berbasis web dapat digunakan oleh surveyor untuk mengumpulkan data tanpa terbatas ruang dan waktu, sehingga responden dapat mengisi kuesioner yang diberikan oleh surveyor kapanpun dan dimanapun secara online melalui website (Atmaja \& Wijaya, 2019). Kuisioner tersebut berisi 10 soal cerita operasi perkalian antara satuan dan puluhan, puluhan dan puluhan hingga puluhan dan ratusan dan menyertakan alasan kesulitan dalam operasi perkalian matematika. Dengan menyertakan kolom alasan, diharapkan peneliti dapat mengalokasikan letak kesulitan siswa SMP dalam mengerjakan soal cerita operasi perkalian.

Metode analisis data dilaksanakan dengan; 1) mengelompokkan rata - rata skor jawaban siswa pada kuisioner berdasarkan kategori skala guttman, 2) mencari persentase hasil tanggapan siswa, 3) menginterpretasi jawaban siswa berdasarkan hasil persentase. Setelah dilakukan penilaian terhadap jawaban responden, maka diuji validitas dengan teknik korelasi Product Moment dan reliabilitasnya menggunakan teknik Cronbach Alpha. Perhitungan kemudian dilakukan dengan menggunakan PASW Statistic 18. Visibilitas kuesioner penelitian dianalisisis reliabilitasnya menggunakan skala Guttman. Skala ini menghasilkan binary skor $(0-1)$, sehingga jawaban hanya diberi skor 1 jika benar dan 0 jika salah. Bilangan adalah sesuatu yang tidak dapat dilihat, ditulis, dibaca dan dikatakan, maka diperlukan adanya simbol ataupun lambang yang digunakan untuk mewakili suatu bilangan yang disebut angka (Saputra \& Febriyanto, 2019).

\section{HASIL DAN PEMBAHASAN}

\section{Penilaian terhadap Jawaban Responden}

Tahapan pertama dalam penelitian ini yakni menduga letak kesulitan siswa Sekolah Menengah Pertama (SMP) yang ada di Provinsi Lampung dalam operasi perkalian. Tahapan kedua yakni, memberikan kuisioner yang berupa soal cerita dalam bentuk google form yang disebar secara cepat dan tepat ke responden. Adapun beberapa fungsi google form untuk dunia pendidikaan menurut Batubara (2016) adalah sebagai berikut: 1) Memberikan tugas latihan/ ulangan online melalui laman website, 2) Mengumpulkan pendapat orang lain melalui laman website, 3) Mengumpulkan berbagai data siswa/ guru melalui halaman website, 4) Membuat formulir pendaftaran online untuk sekolah, 5) Membagikan kuesioner kepada orang-orang secara online.

Soal yang dikemas dalam bentuk esai dengan jawaban singkat dan menyertakan kesulitan siswa dalam mengerjakan soal yang diberikan. Penyusunan soal mengacu pada tingkat kesukaran yang berbeda yaitu mudah, sedang dan sukar. Berikut disajikan kategori soal beserta indikatornya.

Tabel 1. Kuisioner Soal Cerita Operasi Perkalian Menggunakan Google Form

\begin{tabular}{cclcc}
\hline No. & Kategori Soal & \multicolumn{1}{c}{ Indikator } & $\begin{array}{c}\text { Nomor Butir } \\
\text { soal }\end{array}$ & Jumlah \\
\hline 1 & Mudah & $\begin{array}{l}\text { Operasi perkalian antara } \\
\text { puluhan dan satuan, puluhan } \\
\text { dan puluhan. }\end{array}$ & $1,6,9,10$ & 4 \\
2 & Sedang & $\begin{array}{l}\text { Operasi perkalian antara } \\
\text { ratusan dan satuan, ratusan dan } \\
\text { puluhan, ratusan dan ratusan. }\end{array}$ & $3,4,5,8$ & 4 \\
3 & Sukar & $\begin{array}{l}\text { Operasi perkalian antara ribuan } \\
\text { dan satuan, ribuan dan } \\
\text { puluhan. }\end{array}$ & 2,7 & 2 \\
\hline
\end{tabular}

Skala yang digunakan untuk menghitung hasil jawaban responden yaitu skala Guttman. Skala ini menghasilkan binary skor $(0-1)$, sehingga jawaban hanya diberi skor 1 jika benar dan 0 jika salah. Dengan menggunakan skala Guttman, mempermudah peneliti untuk mengumpulkan skor perolehan responden. Berikut data skor perolehan yang dikumpulkan menggunakan google form.

Tabel 2. Hasil Jawaban Responden

\begin{tabular}{ccc}
\hline Butir Soal & $\begin{array}{c}\text { Jawaban } \\
\text { Benar }\end{array}$ & $\begin{array}{c}\text { Jawaban } \\
\text { Salah }\end{array}$ \\
\hline 1 & 24 & 1 \\
2 & 23 & 2 \\
3 & 10 & 15 \\
4 & 15 & 10 \\
5 & 5 & 20 \\
6 & 4 & 21 \\
7 & 6 & 19 \\
\hline
\end{tabular}


Jurnal Ilmiah Matematika Realistik (JI-MR), Vol: 1, No: 1, 1-6

\begin{tabular}{ccc}
8 & 17 & 8 \\
9 & 20 & 5 \\
10 & 14 & 11 \\
Total & $\mathbf{1 3 8}$ & $\mathbf{1 1 2}$ \\
Rata-rata & $\mathbf{1 3 , 8}$ & $\mathbf{1 1 , 2}$ \\
\hline
\end{tabular}

Dari tabel diatas terdapat 138 jawaban benar dengan skor 1 dan 112 jawaban salah dengan skor 0. Dari data diatas dapat dikonversikan ke bentuk persentase.

$$
\begin{aligned}
& \text { Persentase }=\frac{\text { jumlah } \text { jawaban } \text { Benar } \text { rata-rata }}{\text { jumlah } \text { responden }} \times 100 \% \\
& \text { Persentase }=\frac{13,8}{25} \times 100 \% \\
& \text { Persentase }=55 \%
\end{aligned}
$$

jawaban "Salah" tidak perlu dikonversikan karena memperoleh hasil 0\%. Persentase diatas menunjukkan bahwa responden memiliki kesulitan dalam mengerjakan soal cerita operasi perkalian.

\section{Validitas dan Reliabilitas}

Setelah dilakukan penilaian terhadap jawaban responden, maka diuji validitas (dengan analisis butir soal, yaitu mengkorelasikan skor tiap butir soal dengan skor total yang merupakan jumlah tiap skor butir dengan teknik korelasi Product Moment). Validitas adalah suatu ukuran yang akan menunjukkan tingkat kevalidan suatu instrumen. Instrumen yang valid mempunyai nilai validitas yang tinggi, sebaliknya instrumen yang kurang valid mempunyai nilai validitas yang rendah (Setyosari, 2012). Perhitungan kemudian dilakukan dengan menggunakan PASW Statistic 18. Hasil uji validitas menunjukkan bahwa kuesioner valid jika $r_{\text {hitung }}>r_{\text {tabel }}$. Dengan jumlah responden 25 siswa dan tingkat signifikasi 5\%. Berikut hasil validitas butir soal setelah melakukan uji coba produk:

Tabel 3. Hasil Validitas Setelah Uji Coba Produk

\begin{tabular}{cccl}
\hline Butir Soal & $\boldsymbol{r}_{\text {hitung }}$ & Butir Soal & $\boldsymbol{r}_{\text {hitung }}$ \\
\hline 1 & 0,428 & 6 & 0,603 \\
2 & 0,481 & 7 & 0,603 \\
3 & 0,523 & 8 & 0,444 \\
4 & 0,765 & 9 & 0,445 \\
5 & 0,482 & 10 & 0,513 \\
& Nilai Signifikasi $\alpha=5 \%\left(\boldsymbol{r}_{\text {tabel }}=0,396\right)$ \\
\hline
\end{tabular}

Setelah 10 butir soal diuji validitasnya, nampak bahwa $r_{\text {hitung }}>r_{\text {tabel }}$. Dimana $\boldsymbol{r}_{\text {tabel }}=0,396$ dan $\boldsymbol{r}_{\boldsymbol{h i t u n g}} \mathrm{Hal}$ ini menunjukkan bahwa kuesioner yang diberikan kepada responden yang berisi 10 soal cerita operasi perkalian valid. Setelah dilakukan uji validitas, tahap selanjutnya yaitu menguji reliabilitas kuesioner.

Uji reliabilitas yaitu suatu hasil pengukuran dengan menggunakan objek yang sama, akan menghasilkan data yang sama (Sugiyono, 2016). Tujuan dari uji reabilitas itu sendiri adalah untuk melihat apakah kuesioner memiliki konsisten jika pengukuran dilakukan secara berulang. Pengujian ini menggunakan aplikasi $P A S W$ Statistic 18 dengan metode Cronbach Alpha. Menurut Sujerweni (2014) kuesioner dikatakan reliable jika nilai Cronbach Alpha > 0,6. Berikut hasil Reliabilitas setelah uji coba produk.

Tabel 4. Hasil Reliabilitas Setelah Uji Coba Produk

\begin{tabular}{cc}
\hline \multicolumn{2}{c}{ Reliability Statistics } \\
\hline Cronbach's & N of Items \\
Alpha & 10 \\
\hline 707 & \\
\hline
\end{tabular}

Dari perhitungan menggunakanaplikasi PASW Statistic 18, diperoleh nilai realibilitas sebesar 0,707. Ini menunjukkan bahwa kuesioner yang peneliti sebar kepada responden reabel karena nilai Cronbach Alpha 0,707 > 0,6. Hasil perhitungan indeks reliabilitas dapat dilihat pada tabel 4 berdasarkan konsultasi kriteria Guilford.

Tabel 5. Kriteria Guilford.

\begin{tabular}{ccc}
\hline No. & Koefisien Korelasi & Kualifikasi \\
1. & $0,91-1,00$ & Sangat Tinggi \\
2. & $0,71-0,90$ & Tinggi \\
3. & $0,41-0,70$ & Cukup Tinggi \\
4. & $0,21-0,40$ & Rendah \\
\hline
\end{tabular}




5. $\quad$ Negatif $-0,20 \quad$ Sangat Rendah

Hasil perhitungan diatas dapat disesuaikan ke dalam kriteria Guilford. Kuesioner kesulitan operasi perkalian pada siswa Sekolah Menengah Pertama (SMP) masuk ke dalam kriteria tinggi karena hasil perolehan reliabilitas yang sudah di uji menggunakan aplikasi PASW Statistic 18 sebesar 0,707.

\section{Pencapaian Indikator dan Analisis Kesulitan Operasi Perkalian Pada Siswa SMP}

Tahapan selanjutnya yaitu menganalisis kesulitan siswa Sekolah Menengah Pertama (SMP) menggunakan skor yang tidak dapat dicapai dan kolom alasan yang disisipkan dibagian akhir kuesioner. Tujuan dari mengambil skor yang tidak dapat dicapai responden adalah untuk mengetahui sejauh mana responden mengalami kesulitan dalam operasi perkalian. Pada Tabel 6 diperoleh persentase tertinggi yaitu 53\% dimana responden merasa kesulitan saat mengoperasikan perkalian antara ratusan dan satuan, ratusan dan puluhan, ratusan dan ratusan. Kemudian kesulitan responden pada operasi perkalian antara ribuan dan satuan, ribuan dan puluhan dengan perolehan $42 \%$. Terakhir, dengan persentase 38\% untuk kesulitan operasi perkalian antara puluhan dan satuan, puluhan dan puluhan. Sehingga diperoleh rata-rata pencapaian indikator kesulitan operasi perkalian pada siswa Sekolah Menengah Pertama (SMP) menggunakan skor yang tidak dapat dicapai sebesar 37\%.

Tabel 6. Pencapaian Indikator Kesulitan Operasi Perkalian pada Siswa Sekolah Menengah Pertama (SMP)

\begin{tabular}{clccc}
\hline No. & \multicolumn{1}{c}{ Indikator } & $\begin{array}{c}\text { Skor yang } \\
\text { Tidak Dicapai }\end{array}$ & $\begin{array}{c}\text { Skor } \\
\text { Total }\end{array}$ & $\begin{array}{c}\text { Pencapaian } \\
(\%)\end{array}$ \\
\hline 1 & $\begin{array}{l}\text { Operasi perkalian antara } \\
\text { puluhan dan satuan, puluhan } \\
\text { dan puluhan. }\end{array}$ & 38 & 100 & 38 \\
2 & $\begin{array}{l}\text { Operasi perkalian antara } \\
\text { ratusan dan satuan, ratusan dan } \\
\text { puluhan, ratusan dan ratusan. } \\
\text { Operasi perkalian antara ribuan } \\
\text { dan satuan, ribuan dan } \\
\text { puluhan. } \quad \text { Rata-rata pencapaian }\end{array}$ & 53 & 100 & 53 \\
\hline
\end{tabular}

Selain menganalisis kesulitan siswa menggunakan indikator skor yang tidak dapat dicapai, penulis juga menganalisis kesulitan 25 siswa menggunakan kolom alasan saat mengerjakan 10 soal cerita operasi perkalian yang telah disisipkan penulis di akhir kuesioner.

Tabel 7. Alasan Kesulitan Responden Diperoleh dari Google Form

\begin{tabular}{clcc}
\hline No. & \multicolumn{1}{c}{ Alasan Kesulitan } & $\begin{array}{c}\text { Banyak } \\
\text { Responden }\end{array}$ & $\begin{array}{c}\text { Persentase } \\
(\%)\end{array}$ \\
\hline 1 & $\begin{array}{l}\text { Sulit memahami soal yang } \\
\text { diberikan. }\end{array}$ & 10 & 40 \\
2 & $\begin{array}{l}\text { Tidak teliti. } \\
\text { Sulit menghitung skala waktu. }\end{array}$ & 3 & 12 \\
3 & $\begin{array}{l}\text { Seperti : bulan, menit, detik, } \\
\text { dll. } \begin{array}{l}\text { Banyak angka yang mengecoh. } \\
\text { Total }\end{array}\end{array}$ & 8 & 32 \\
& $\quad \begin{array}{c}16 \\
2\end{array}$ \\
\hline
\end{tabular}

Dari Tabel 7, didapat bahwa responden sulit memahami soal yang diberikan dengan perolehan persentase sebesar $40 \%$. Ini menunjukkan bahwa siswa mengalami kesulitan mengoperasikan perkalian dimulai dari sulitnya memahami maksud soal. Selanjutnya kurang memahami jumlah skala waktu seperti jumlah menit, detik, bulan dan hari yang disisipkan pada soal cerita menjadi posisi persentase tertinggi ke-dua dengan perolehan $32 \%$. Penulis tentunya membuat pengecoh soal dengan menyisipkan angka yang tidak dipakai untuk menjawab soal, penulis menyisipkan pada kategori soal sukar. Ini bertujuan untuk mengetahui sejauh mana tingkat pemahaman responden dalam memahami soal yang diberikan. Dalam hal ini, 4 responden menyadari adanya hal tersebut. Sehingga diperoleh $16 \%$ untuk alasan responden tentang angka pengecoh. Terakhir, hal yang sering dilakukan oleh responden yaitu tidak teliti saat membaca soal dan mengalikan angka sebesar $12 \%$.

Solusi untuk mengatasi kesulitan operasi perkalian pada siswa Sekolah Menengah Pertama (SMP) yaitu perlunya fondasi yang cukup kuat dan matang pada operasi hitung matematika saat jenjang Sekolah Dasar. Sehingga saat memasuki jenjang berikutnya siswa lebih siap untuk memahami dan mengoperasikan angka ke dalam operasi perkalian. Serta pemilihan metode yang baik saat materi operasi perkalian akan mempengaruhi tingkat keberhasilan siswa. Dengan begitu, siswa dirasa lebih siap dan matang untuk memasuki jenjang selanjutnya. 


\section{SIMPULAN}

Berdasarkan analisis terhadap data yang telah dikumpulkan melalui tes yang dilakukan menggunakan google form dan alasan siswa dalam kesulitan operasi perkalian yang disajikan dalam bentuk soal cerita esai. Diperoleh bahwa letak kesulitan operasi perkalian pada siswa Sekolah Menengah Pertama (SMP) adalah sulit memahami maksud soal mencapai $40 \%$, kesulitan inilah yang memicu kesulitan-kesulitan lainnya mucul. Mulai dari operasi perkalian satuan, puluhan, ratusan hingga ribuan.

Saran peneliti yaitu pemilihan metode pembelajaran yang baik dan cocok sangat disarankan guna kelangsungan proses pembelajaran. Membuat suasana lebih menyenangkan dan asik saat pembelajaran matematika akan menumbuhkan semangat siswa untuk belajar. Serta, perlunya mengasah pemahaman siswa melalui soal-soal cerita dengan begitu diharapkan siswa bisa lebih bernalar dan memahami maksud dari soal.

\section{REFERENSI}

Amri, M., \& Abadi, A. (2013). Pengaruh PMR dengan TGT terhadap motivasi, sikap, dan kemampuan pemecahan Masalah geometri kelas VII SMP. PYTHAGORAS: Jurnal Pendidikan Matematika.h 8(1), 55-68.

Atmaja, K. J., \& Wijaya, I. N. S. W. (2019). Pengembangan Sistem Evaluasi Kinerja Dosen (E-Kuesioner) Stmik Stikom Indonesia. JST (Jurnal Sains Dan Teknologi). 8(1), 5564.

Batubara, H. H. (2016). Penggunaan Google Form Sebagai Alat Penilaian Kinerja Dosen di Prodi PGMI UNISKA Muhammad Arsyad AlBanjari. Al-Bidayah: Jurnal Pendidikan Dasar Islam, 8(1), 39-50.

Hidayat, W. (2017). Adversity quotient dan Penalaran Kreatif Matematis Siswa SMA dalam Pembelajaran Argument Driven Inquiry pada Materi Turunan Fungsi. KALAMATIKA Jurnal Pendidikan Matematika. 2(1), 15- 28.

Hidayat, W., \& Sariningsih, R. (2018). Kemampuan Pemecahan Masalah Matematis dan Adversity Quotient Siswa SMP

Melalui Pembelajaran Open Ended. Jurnal JNPM (Jurnal Nasional Pendidikan Matematika). 2(1), 109-118.

Ismail, I., \& AlBahri, F. P. (2019). Perancangan E-Kuisioner menggunakan CodeIgniter dan React Js sebagai Tools

Pendukung Penelitian. J-SAKTI (Jurnal Sains Komputer Dan Informatika). 3(2), 337-347.

Maskar, S. \& Anderha, R. R. (2019). Pembelajaran Transformasi Geometri dengan Pendekatan Motif Kain Tapis Lampung. Mathema: Jurnal Pendidikan Metematika. 1(1), 40-47

Muhajarah, K. (2018). Krisis Manusia Modern dan Pendidikan Islam. Al Ta'dib. 7(2), 188-204

Muchlis, M., Christian, A., \& Sari, M. P. (2019). Kuesioner Online Sebagai Media Feedback Terhadap Pelayanan Akademik Pada STMIK Prabumulih. Eksplora Informatika, 8(2), 149-157.

Puspaningtyas, N. D. (2019). Berpikir Lateral Siswa SD dalam Pembelajaran Matematika. Mathema: Jurnal Pendidikan Matematika. 1(1), 25-30

Saputra, V. H. \& Febriyanto, E. (2019). Media Pembelajaran Berbasis Multimedia Untuk Anak Tuna Grahita. Mathema: Jurnal Pendidikan Matematika. 1(1), 15-23

Sariningsih, R., \& Purwasih, R. (2017). Pembelajaran Problem Based Learning Untuk Meningkatkan Kemampuan Pe mecahan Masalah Matematis Dan Self Efficacy Mahasiswa Calon Guru. Jurnal Nasional Pendidikan Matematika. 1 (1), 163177.

Setyosari, punaji. (2012). Metode Penelitian Pengembangan. Jakarta: Kencana

Sugiyono. (2016). Metode Penelitia n Kombinasi (8th ed.). Bandung: Alfabeta.

Supardi, U.S. (2013). Pengaruh Adversity quotient Terhadap Prestasi Belajar Matematika. Jurnal Formatif. 3(1), 61-71

Suryabrata, S. (2014). Psikologi pendidikan. Jakarta: PT. Raja Grafindo Persada

Ulfa, M. (2019). Strategi Preview, Question, Read, Reflect, Recite, Review (PQ4R) pada Pemahaman Konsep Matematika. Mathema Journal Pendidikan Matematika. 1(1), 48-55.

Untari, Erny. (2013). Diagnosis Kesulitan Belajar Pokok Bahasan Pecahan pada Siswa Kelas V Sekolah Dasar. Jurnal Ilmiah STKIP PGRI Ngawi. 13(1). 1-8.

Wulandari, Ika \& Sagita, Laela. (2011). Pembelajaran Matematika dengan Differentiated Instruction untuk Mengembangkan Karakter Positif Siswa. PROSIDING Seminar Nasional Matematika dan Pendidikan Matematika: Matematika dan Pendidikan Karakter dalam Pembelajaran. 273-282.

Putri, L.A., \& Dewi, P.S. (2020). Media Pembelajaran Menggunakan Video Atraktif pada Materi Garis Singgung Lingkaran. Mathema Journal Pendidikan Matematika. 2(1), 32-39. 